\title{
Earliest Cretaceous mammals from the western United States
}

\author{
Richard L. Cifelli, Brian M. Davis, and Benjamin Sames \\ Acta Palaeontologica Polonica 59 (1), 2014: 31-52 doi: http://dx.doi.org/10.4202/app.2012.0089
}

Mammalian diversity in North America shifted significantly during the Early Cretaceous, from archaic groups dominant in the well-sampled faunas of the Late Jurassic to advanced forms (including early members of modern clades) by the Albian-Cenomanian. However, the dynamics of this transition are poorly understood, since faunas of earliest Cretaceous age are unknown. Here we describe the first fossil mammals from exposures of the Lakota Formation in the Black Hills of South Dakota, a unit correlated with the upper Berriasian-lower Barremian and positioned stratigraphically between the underlying Morrison Formation and Aptian-Albian units exposed elsewhere in North America. The mammalian fauna from the Lakota Formation is transitional with regard to the North American fossil record, representing a broad spectrum of both Jurassic and Cretaceous lineages: present are "plagiaulacidan" multituberculates allied with Late Jurassic Allodontoidea and Early Cretaceous Plagiaulacoidea; the geologically youngest dryolestoid(s) and "triconodontine" triconodontids (characteristic Late Jurassic taxa from the Morrison Formation); the oldest spalacotheriid "symmetrodont"; the first record of an amphitheriid-like stem zatherian from North America (abundant in the Middle Jurassic-earliest Cretaceous of Europe); and the oldest North American tribosphenic mammal (abundant and diverse on the continent by the end of the Early Cretaceous). Taxa making their first North American appearance in the Lakota Formation (Plagiaulacoidea, including a genus also known from the Purbeck of Britain; Spalacotheriidae, stem Zatheria, Tribosphenida) are also known from the Early Cretaceous of Western Europe, suggesting the possibility that they represent immigrants.

Key words: Mammalia, Multituberculata, Triconodontidae, Spalacotheriidae, Dryolestoidea, Zatheria, Tribosphenida, Lakota Formation, Cretaceous, North America.

Richard L. Cifelli [rlc@ou.edu], Sam Noble Museum, 2401 Chautauqua Ave.,

Norman, OK 73072 USA; Brian M. Davis [bm.davis@louisville.edu], Department of Biology and Environmental Health, Missouri Southern State University, 3950 E. Newman Rd., Joplin, MO 64801, USA, and Sam Noble Museum, 2401 Chautauqua Ave., Norman, OK 73072 USA; Benjamin Sames [benjamin.sames@univie.ac.at], Universität Wien, Department für Geodynamik und Sedimentologie, and Institut für Paläontologie, Geozentrum, Althanstrasse 141090 Wien, Austria, and Sam Noble Museum, 2401 Chautauqua Ave., Norman, OK 73072 USA. 
This is an open-access article distributed under the terms of the Creative Commons Attribution License (for details please see creativecommons.org), which permits unrestricted use, distribution, and reproduction in any medium, provided the original author and source are credited.

Fafill text $(755.2 \mathrm{kB})$ 